\title{
Perlindungan Terhadap Kepentingan Kreditor Melalui Actio Pauliana
}

\author{
Siti Anisah \\ Fakultas Hukum Universitas Islam Indonesia \\ nisa@fh.uii.ac.id
}

\begin{abstract}
Generally, the procedure to prove the application of actio pauliana is not simple. In addition to this, the application for the settlement of actio pauliana is lack or coordination among the relevant authorities. It is considered therefore that the protection on creditor's interest through actio pauliana is possible to be enforced. More than this, further regulation on the implementation of the procedure to prove actio pauliana which is implementable is highly demanded.
\end{abstract}

Keywords: Act Of Bankruptcy, Creditor, Actio Pauliana

\section{Pendahuluan}

Salah satu upaya perlindungan terhadap kepentingan kreditor dalam Undang-Undang Kepailitan adalah mencegah kecurangan yang dilakukan oleh debitor. ${ }^{1}$ Kecurangan yang dapat dilakukan oleh debitor misalnya seseorang yang beriktikad tidak baik membuat sebanyak mungkin utang untuk selanjutnya mengajukan permohonan pernyataan pailit agar tidak membayar utang-utangnya itu dengan terlebih dahulu menyembunyikan kekayaannya. Contoh lainnya, seseorang menyalahgunakan pernyataan pailit sebagai "kamuflase" demi untuk menutupi iktikad tidak baiknya dengan cara mengalihkan modal dan kekayaan kepada perusahaan yang baru dibentuk atau pihak lain. ${ }^{2}$

\footnotetext{
${ }^{1}$ Max Radin menyatakan: "The object of the avoidance remedies under Roman law was "the preservation of the corpus of the debtor's estate for the proportionate benefit of creditors in the context of the Roman systems of collective proprietary execution" dalam Frank R. Kennedy "Involuntary Fraudulent Transfers" 9 Cardozo L. Rev. 531, Desember, 1987, hlm. 535.

${ }^{2}$ Victor Situmorang \& Hendri Soekarso, Pengantar Hukum Kepailitan di Indonesia Jakarta: Rineka Cipta, 1994, hlm. 13.
} 
Tindakan-tindakan debitor tersebut dalam hukum kepailitan Indonesia termasuk sebagai actio pauliana. Actio pauliana diatur baik dalam Faillissementsverordening, Undang-Undang Nomor 4 Tahun 1998 maupun Undang-Undang Nomor 37 Tahun 2004. Kreditor mempunyai hak untuk mengajukan pembatalan kepada Pengadilan terhadap segala perbuatan yang dilakukan oleh debitor sebelum dinyatakan pailit, karena perbuatan tersebut tidak diwajibkan, dan debitor mengetahui bahwa perbuatan tersebut akan merugikan kepentingan kreditor. ${ }^{3}$ Untuk itu bagaimana penerapan actio pauliana dalam putusan Pengadilan Niaga? Apakah Pengadilan Niaga telah memberikan perlindungan terhadap kepentingan kreditor melalui actio pauliana? Apa saja kendala yang ditemukan dalam penerapan actio pauliana?

\section{Actio Pauliana dalam Suatu Kajian Perbandingan}

Actio Pauliana merupakan perbuatan hukum yang dilakukan oleh debitor sebelum ia dinyatakan pailit, perbuatan hukum tersebut tidak diwajibkan, dan debitor mengetahui bahwa perbuatan hukum tersebut merugikan kepentingan kreditor. ${ }^{4}$ Kreditor mempunyai hak untuk mengajukan pembatalan kepada Pengadilan terhadap perbuatan hukum yang dilakukan oleh debitor sebelum dinyatakan pailit yang mengakibatkan kerugian bagi kreditor. Debitor atau pihak dengan siapa perbuatan hukum tersebut dilakukan dapat membuktikan sebaliknya bahwa mereka mengetahui atau patut mengetahui bahwa perbuatan hukum tersebut tidak mengakibatkan kerugian bagi kreditor. ${ }^{5}$ Permohonan pembatalan atas perbuatan hukum yang dilakukan oleh debitor diajukan dalam rangka pemberesan harta pailit. Tujuannya adalah untuk memperbanyak harta pailit, agar para kreditor memperoleh pembayaran secara maksimal sesuai dengan jumlah piutang yang dimiliki oleh para kreditor. ${ }^{6}$

Actio pauliana sebagai lembaga yang melindugi kepentingan kreditor memiliki beberapa persyaratan yang bersifat kumulatif. Pertama, debitor

\footnotetext{
${ }^{3}$ Pasal 41 Undang-Undang Nomor 4 Tahun 1998 dan Undang-Undang Nomor 37 Tahun 2004.

${ }^{4}$ Lihat lebih lanjut Pasal 41- 44 Undang-Undang Nomor 4 Tahun 1998 dan Pasal 41 - 49 Undang-Undang Nomor 37 Tahun 2004.

${ }^{5}$ Perbuatan hukum yang termasuk sebagai actio pauliana dapat dilihat pada Pasal 42 Undang-Undang Nomor 37 Tahun 2004.

${ }^{6}$ Elijana, et. al., Penelitian Hukum tentang Penyelesaian Sengketa melalui Peradilan Niaga, Jakarta: BPHN dan Depkeh dan HAM, 2000, hlm. 15
} 
telah melakukan suatu perbuatan hukum. Kedua, perbuatan hukum tersebut tidak wajib dilakukan oleh debitor. Ketiga, perbuatan hukum tersebut telah merugikan kepentingan kreditor. Keempat, pada saat melakukan perbuatan hukum tersebut debitor mengetahui atau sepatutnya mengetahui bahwa perbuatan hukum yang dilakukannya akan merugikan kepentingan kreditor; dan kelima, pada saat perbuatan hukum tersebut dilakukan pihak dengan siapa perbuatan hukum itu dilakukan mengetahui atau sepatutnya mengetahui bahwa perbuatan hukum tersebut akan mengakibatkan kerugian bagi kreditor. ${ }^{7}$

Sebagai perbandingan pengaturan actio pauliana di Indonesia dapat dikemukakan pengaturan fraudulent transfer law di Amerika Serikat dan claw back di Italia. Sejarah fraudulent transfer law modern di Amerika Serikat berasal dari England's Statute of 13 Elizabeth, yang disahkan pada $1571 .^{8}$ Selanjutnya berkembang menjadi Uniform Fraudulent Conveyance Act (UFCA), the Bankruptcy Act of 1975, dan the Uniform Fraudulent Transfer Act (UFTA). ${ }^{9}$ Sejak awal, the Statute of 13 Elizabeth melarang transfer harta kekayaan yang dilakukan oleh debitor yang berniat untuk "menghalangi, menunda, atau menipu" kreditornya. ${ }^{10}$ Dengan demikian, fraudulent transfer law dibuat dengan tujuan untuk mencegah debitor melakukan manipulasi dengan cara melakukan transfer harta kekayaan yang dibuat oleh debitor sebelum pernyataan pailit sehingga mengurangi atau menghabiskan harta kekayaan debitor. Tujuan lain dari fraudulent transfer law adalah untuk

${ }^{7}$ Fred B.G. Tumbuan, “Mencermati Pokok-pokok Undang-Undang Kepailitan yang Diubah Perpu No. 1/1998," Newsletter No. 33/IX/Juni/1998, hlm. 3. Kelima persyaratan tersebut terdapat dalam Pasal 41 Undang-Undang Nomor 4 Tahun 1998 dan Undang-Undang Nomor 37 Tahun 2007.

${ }^{8}$ Douglas G. Baird \& Thomas H. Jackson, "Fraudulent Conveyance Law and its Proper Domain," 38 Vand. L. Rev. 829, 1985, hlm. 829.

${ }^{9}$ Kata "transfer" dan "conveyance" sebenarnya mempunyai pengertian yang sama. Penggantian kata "transfer" untuk "conveyance" dalam UFTA dimaksudkan untuk menegaskan bahwa ketentuan yang baru mengacu kepada transfer terhadap real property as well as personal property. Lihat Rosenberg, "Intercorporate Guaranties and the Law of Fraudulent Conveyances: Lender Beware," 125 U. Pa. L. Rev. 235, 1976, hlm. 241. Untuk memahami lebih lanjut perbedaan mendasar antara UFCA dengan UFTA lihat Acles \& Dorr, "A Critical Analysis of the New Uniform Fraudulent Transfer Act," 1985 U. Ill. L. Rev. 527, 1985; Cook \& Mendales, “Uniform Fraudulent Transfer Act: An Introductory Critique," 62 Am. Bankr. L. J. 87, 1988.

${ }^{10}$ Douglas G. Baird \& Thomas H. Jackson," loc. cit.; dan Daniel V. Davidson, et. al., Comprehensive Business Law Prinsiples and Cases, Boston: Kent Publishing Company, 1987, hlm. 674. 
mencegah debitor menutupi atau menjual harta kekayaannya untuk menipu para kreditornya. ${ }^{11}$

Dalam perkembangannya, the Bankruptcy Code memperluas fraudulent transfer hingga mencakup constructively fraudulent transfers. ${ }^{12}$ Constructive fraud terjadi ketika debitor menjual harta kekayaannya dengan harga rendah, dan dari hasil penjualan harta kekayaannya menyebabkan debitor menjadi pailit, atau jika debitor telah pailit ketika penjualan harta kekayaan yang tidak masuk akal itu dilakukan oleh debitor. Dengan demikian, constructive fraud termasuk didalamnya adalah melakukan bisnis yang undercapitalized. ${ }^{13}$ Selanjutnya fraudulent transfer juga termasuk actual fraud, yang terjadi apabila debitor berniat untuk menghalangi atau menunda pembayaran utangnya kepada kreditor. ${ }^{14}$ Apabila debitor melakukan perbuatan-perbuatan itu, maka perbuatannya dapat dibatalkan.

Berdasarkan Bankruptcy Code dan undang-undang lain yang berlaku di Amerika Serikat, tidak jelas apakah kreditor yang menerima jasa dari debitor yang dilakukan tanpa mengurangi atau merugikan harta kekayaannya harus mengembalikan nilai dari jasa yang telah diterimanya. ${ }^{15}$ Ketidakjelasan ini berasal dari pengaturan fraudulent transfer yang hanya berhubungan dengan transfer harta kekayaan, dan bukan transfer jasa. ${ }^{16}$ Dengan demikian, pertanggungjawabannya pun berkaitan dengan transfer harta kekayaan, dan bukan transfer jasa. ${ }^{17}$ Namun demikian Bankruptcy Court mengkategorikan jasa sebagai harta kekayaan sebagai objek fraudulent transfer law, sehingga kreditor mempunyai kekuasaan untuk menagih nilai jasa tersebut kepada pihak ketiga sebagai penerima transfer jasa. Penentuan apakah jasa dianggap harta kekayaan, berdasarkan fraudulent transfer law dapat diuji oleh Pengadilan dengan menggunakan salah satu tujuan UndangUndang Kepailitan yaitu apakah maksimalisasi aset debitor untuk keuntungan kreditor terpenuhi. ${ }^{18}$

\footnotetext{
${ }^{11}$ John D. Donell, et. al., Law for Business, Illionis: Richard D. Irwin, Inc., 1983) hlm. 47.

${ }^{12}$ McCoid, "Constructively Fraudulent Conveyances: Transfers for Inadequate Consideration," 62 Tex. L. Rev. 639, 1983, hlm. 647 - 648.

${ }^{13}$ Daniel V. Davidson, et. al., loc. cit.

${ }^{14}$ Ibid.

${ }^{15} 11$ U.S.C. $\S 541(a)$.

${ }^{16} 11$ U.S.C. $\$ 548$.

${ }^{17}$ Oksana Lashko, "Enhancing Creditor Recovery, Should Services Be Deemed "Property" for the Putpose of Fraudulent Transfer Law?" 72 Brook. L. Rev. 317, 2006, hlm. $318-319$.

${ }^{18}$ Ibid., hlm. 319.
} 
Selanjutnya, apakah jasa yang diberikan oleh debitor kepada pihak ketiga dapat dianggap sebagai transfer harta kekayaan debitor, karena menurut definisi tradisional istilah jasa bukan merupakan harta kekayaan? ${ }^{19}$ Jasa yang diberikan oleh debitor kepada pihak ketiga bukan merupakan transfer harta kekayaan debitor. Pandangan ini menurut teori "underlying chattel" yang menyatakan jasa tidak termasuk harta kekayaan, kecuali mereka "culminate in transferable property". ${ }^{20}$ Dengan perkataan lain, jika pelaksanaan transfer jasa yang mengurangi atau merugikan harta kekayaan debitor menyebabkan adanya peralihan harta kekayaan debitor terhadap penerimanya, maka hal ini dianggap transfer harta kekayaan oleh Bankruptcy Court. Sebaliknya, jika transfer jasa yang dilakukan tidak mengurangi atau merugikan harta kekayaan debitor dianggap sebagai suatu keuntungan, maka kreditor tidak menganggap jasa tersebut sebagai transfer harta kekayaan debitor.

Pada awalnya bentuk dasar penipuan debitor kepada kreditornya adalah transfer harta kekayaan pada saat sebelum pernyataan pailit. ${ }^{21}$ Dalam perkembangan selanjutnya, batasan fraudulent transfer law menjadi kurang jelas ketika debitor yang dalam keadaan berhenti membayar utangnya tidak mentransfer harta kekayaannya melainkan mentransfer jasa yang tidak mengurangi atau merugikan harta kekayaannya. ${ }^{22}$

Di Italia, actio pauliana atau claw back diatur dalam Italian Insolvency Law dalam Law Decree No. 35, 14 Maret 2005 yang diubah menjadi Law 80 pada 14 Mei 2005. Tindakan berikut ini dapat disebut sebagai clawed back, kecuali pihak lain dapat membuktikan bahwa ia tidak mengetahui jika debitor dalam keadaan berhenti membayar utang-utangnya. Pertama, semua tindakan dengan pertimbangan (a titolo oneroso) yang dilakukan pada tahun-tahun sebelum insolvensi di mana suatu perbuatan telah dilakukan atau suatu hak yang telah diperoleh oleh pihak lain dengan siapa debitor melakukan perjanjian mencapai seperempat dari yang diterima oleh pihak yang pertama telah melakukan perjanjian. Kedua, semua pembayaran (atto estintivo) terhadap kewajiban keuangan yang

${ }^{19}$ Ibid.

${ }^{20}$ Ibid., hlm. 320.

${ }^{21} 11$ U.S.C. $\S 548$.

${ }^{22}$ Michael Bagge, "Planned Poverty's Pitfalls And Pratfalls - Ain't We Got Fun?" 69-Aug N.Y. St. B.J. 26; Juli/Agustus, 1997, hlm. 27. Contoh kasus pemberian jasa kesehatan yang tidak sesuai dengan standar yang ditentukan oleh peraturan perundang-undangan yang berlaku sebagai fraudulent transfer, dapat dilihat dalam Dawson v. Myers, 622 F 2d. 1304, 9th Cir. 1980. 
telah jatuh tempo dan dapat ditagih, tetapi pembayarannya dilakukan dalam jangka waktu satu tahun sebelum pernyataan pailit untuk utangutang yang belum jatuh tempo dan dapat ditagih. Ketiga, semua janji, biaya, hipotik yang dibuat dalam jangka waktu enam bulan sebelum pernyataan pailit untuk utang-utang yang pada saat permohonan pailit jatuh tempo dan dapat ditagih. Keempat, jika likuidator dapat membuktikan bahwa pihak lain mengetahui pernyataan pailit terhadap debitor, namun debitor tetap melakukan tindakan yang relevan untuk pembayaran utang yang telah jatuh tempo dan dapat ditagih. Tindakan ini dilakukan berdasarkan pertimbangan, dan tindakannya merupakan sebuah keistimewaan (diritto di prelazione) terhadap utang-utang yang dibuat pada saat yang sama; juga bagi pihak ketiga, dalam setiap kasus jika dibuat dalam jangka waktu enam bulan pada saat pernyataan insolvensi. ${ }^{23}$

\section{Putusan Permohonan Actio Pauliana oleh Pengadilan Niaga}

Pada masa berlakunya Undang-Undang Nomor 4 Tahun 1998 dapat ditemukan permohonan actio pauliana yang diajukan oleh kurator ditolak oleh Pengadilan Niaga Jakarta Pusat karena kekeliruan yang sebenarnya dilakukan oleh kurator dalam melakukan pengumpulan harta pailit. Permohonan actio pauliana yang ditolak oleh Pengadilan Niaga tersebut terdapat dalam William E. Daniel kurator PT Ometraco Multi Arta v. PT Ometraco Multi Arta, dkk. ${ }^{24}$

Permohonan ini berawal dari perbuatan PT Ometraco Multi Arta selaku debitor yang menyetujui pelunasan utang PT Duta Trada Internusa sebesar Rp 43.976.666.974,00 yang telah jatuh tempo pada 23 Februari 1998, 26 Januari 1998 dan 10 Maret 1998 dengan cara menerima penyerahan kepemilikan obligasi PT Ekagunatama Mandiri dengan nilai nominal Rp 12.006.000.000,00 berikut kupon bunga sebesar Rp 132.232.750,00 dan kepemilikan obligasi PT Ciputra Surya I dengan nilai nominal sebesar Rp 31.000.000.000,00 berikut kupon bunga sebesar Rp

${ }^{23}$ Sandy Shandro, "Italian Law Reform,” 24 Am. Bankr. Inst. J. 18, Oktober, 2005, hlm. 18 - 19. Lihat pula Marco Lantelme, "Italy: Insolvency - Claw Back," J.I.B.L.R 20 (10), 2005, hlm. 95 - 96.

${ }^{24}$ Putusan Pengadilan Niaga dalam William E. Daniel kurator PT Ometraco Multi Arta v. PT Ometraco Multi Arta, dkk., Nomor 01/Actio Pauliana/2000/PN.Niaga/ Jkt.Pst., dan Putusan Mahkamah Agung pada tingkat kasasi, Nomor 15 K/N/2000. 
775.000.000,00 dengan memperhitungkan obligasi-obligasi berdasarkan keseluruhan nilai nominalnya sebesar Rp 43.913.232.750,00 nilainya hanya dapat dicairkan pada saat jatuh tempo obligasi-obligasi tersebut yaitu 28 Juli 2002, untuk obligasi PT Citra Surya I, dan 25 Juni 2003 untuk obligasi PT Ekagunatama Mandiri. Menurut prinsip yang berlaku dalam praktik perdagangan obligasi, obligasi yang belum jatuh tempo seharusnya dinilai berdasarkan nilai pasarnya pada saat obligasi tersebut dialihkan atau dijual. Berdasarkan nilai pasar obligasi PT Citra Surya I adalah 17,5\% dari nilai nominalnya dan nilai pasar obligasi PT Ekagunatama Mandiri adalah $31,5 \%$ dari nilai nominalnya, sehingga seharusnya pada saat itu yang dapat dianggap sebagai pelunasan utang hanyalah sebesar Rp 9.342.515.000,00 bukan Rp 43.976.666.974,00. Tindakan debitor PT Ometraco Multi Arta yang menghargai obligasi-obligasi sebesar 100\% dari nilai nominalnya merupakan tindakan yang melanggar kepatutan dan kebiasaan. Debitor dianggap mengetahui atau sepatutnya mengetahui tindakannya yang menghapuskan utang PT Duta Trada Internusa adalah merugikan kepentingan para kreditor PT Ometraco Multi Arta. Terhadap permohonan actio pauliana tersebut Pengadilan Niaga Jakarta Pusat memutuskan untuk menolaknya. Selanjutnya William E. Daniel selaku kurator mengajukan permohonan kasasi kepada Mahkamah Agung. Mahkamah Agung pada tingkat kasasi memutuskan menolak permohonan kurator dengan pertimbangan judex factie tidak salah menerapkan hukum. Permasalahan yang ada adalah utang PT Duta Trada Internusa kepada PT Ometraco Multi Artha yang telah disetujui pelunasannya dan jatuh tempo pada 23 Februari 1998, 26 Januari 1998 dan 10 Maret 1998. Debitor PT Ometraco Multi Artha pada 13 November 1998 dinyatakan pailit. Kurator debitor telah menjual atau mengeksekusi obligasi-obligasi tersebut di bawah harga melalui pialang PT Citramas Securindo dan pialang PT Sentra Investindo seharga Rp 8.157.182.750,00, sehingga harga tidak sesuai dengan harga yang disetujui oleh debitor PT Ometraco Multi Artha dan PT Duta Trada Internusa, sehingga mengakibatkan kerugian bagi kreditor PT Ometraco Multi Artha. Mahkamah Agung berpendapat seharusnya kurator memberitahukan terlebih dahulu kepada PT Ometraco Multi Artha dan PT Duta Trada Internusa atau mengembalikan obligasiobligasi tersebut atau kurator menunggu sampai obligasi jatuh tempo, sehingga akan terlihat apakah tindakan PT Ometraco Multi Artha dan PT Duta Trada Internusa merugikan kreditor-kreditornya atau tidak. Kurator tidak seharusnya mengajukan actio pauliana setelah kurator sendiri 
menjual obligasi-obligasi tersebut. Apa yang dilakukan oleh PT Ometraco Multi Artha dan PT Duta Trada Internusa tidak terbukti telah merugikan kepentingan kreditor.

Pada kasus yang lain actio pauliana diajukan oleh kurator, karena kurator menemukan bukti debitor melakukan perbuatan yang telah merugikan harta pailit. Namun, Mahkamah Agung menolak memeriksa actio pauliana yang diajukan oleh kurator, sebab actio pauliana sebagai pembatalan perbuatan hukum debitor yang telah dinyatakan pailit dengan pihak ketiga, merupakan suatu sengketa yang penyelesaiannya harus dilakukan melalui suatu gugatan perdata kepada Pengadilan Negeri, dan suatu permohonan tidak lah merupakan suatu sengketa. Pandangan Mahkamah Agung tersebut terdapat dalam Tuti Simorangkir, Kurator PT Fiskaragung Perkasa Tbk. v. PT Fiskaragung Perkasa Tbk. dkk. ${ }^{25}$

Permohonan ini berawal ketika kurator melakukan pemeriksaan seksama atas seluruh aset maupun dokumen perjanjian yang dibuat antara debitor yakni PT Fiskaragung Perkasa Tbk. dengan pihak ketiga. Kurator mencurigai debitor melakukan perbuatan yang telah merugikan harta pailit. Perbuatan yang dimaksud adalah ditandatanganinya perjanjian utang antara debitor dengan Catnera International Limited selaku kreditor dengan jumlah utang pokok sebesar US \$ 3.000.000,00 pada 1 Maret 1999. Selanjutnya debitor memberikan jaminan pelunasan utang kepada Catnera. Dengan menandatangani perjanjian jaminan dengan Catnera merupakan perbuatan curang yang sangat merugikan para kreditor lainnya. Sekiranya debitor tidak menandatangani perjanjianperjanjian jaminan tentunya Catnera akan berada pada posisi yang sama atau sederajat dengan para kreditor lainnya, sehingga seluruh harta pailit akan dapat dibagi secara proporsional di antara seluruh kreditor. Adanya perjanjian jaminan Catnera akan memiliki privilege, karena atas piutangnya Catnera mendapat jaminan yang dapat dieksekusi tanpa harus dibagi dengan para kreditor lainnya padahal jumlah piutang Catnera hanya US \$3.000.000,00. Jumlah tersebut sangat kecil jika dibandingkan dengan

${ }^{25}$ Putusan Pengadilan Niaga dalam Tuti Simorangkir, Kurator PT Fiskaragung Perkasa Tbk. v. PT Fiskaragung Perkasa Tbk. dkk., Nomor 03/Actio Pauliana/2000/ PN.Niaga/Jkt.Pst., Putusan Mahkamah Agung pada tingkat kasasi Nomor 16 K/N/ 2000, dan Putusan Mahkamah Agung pada tingkat peninjauan kembali Nomor 12 PK/N/2000. Selain PT Fiskaragung Perkasa Tbk. (dalam pailit) terdapat pula Catnera International Limited selaku pihak yang dimohonkan actio pauliana, sedangkan kreditor lain dalam kasus ini adalah Hanil Leasing \& Finance (HK), Ltd., et. al. 
piutang para pemegang medium term note, yang jumlah pokoknya saja mencapai US \$29.000.000,00. Pengadilan Niaga memutuskan menolak permohonan actio pauliana yang diajukan kurator dan menyatakan Catnera Internasional Limited adalah kreditor separatis yang sah dari Fiskaragung Perkasa Tbk.

Selanjutnya kurator mengajukan permohonan kasasi kepada Mahkamah Agung. Mahkamah Agung menolak permohonan kasasi yang diajukan kurator dengan pertimbangan, kurator tidak dapat dibenarkan menarik debitor sebagai pihak atau termohon dalam permohonan a quo, karena menurut logika hukum adalah tidak tepat apabila seorang kurator menuntut atau menggugat pihak yang diwakilinya. Terhadap putusan Mahkamah Agung pada tingkat kasasi, kurator mengajukan peninjauan kembali. Mahkamah Agung pada tingkat peninjauan kembali menyatakan keberatan kurator dapat dibenarkan, karena putusan tingkat kasasi terdapat kesalahan berat. Permohonan yang diajukan oleh kurator adalah pembatalan perbuatan hukum debitor yang telah dinyatakan pailit dengan pihak ketiga atau actio pauliana, sehingga dengan belum diperiksanya pokok perkara seharusnya Mahkamah Agung menyatakan permohonan kurator tidak dapat diterima.

Mahkamah Agung pada tingkat peninjauan kembali berpendapat sesuai dengan Pasal 280 ayat (2) Undang-Undang Nomor 4 Tahun 1998, kewenangan Pengadilan Niaga hingga saat ini adalah memeriksa dan memutus permohonan pernyataan pailit dan penundaan kewajiban pembayaran utang serta permohonan lain yang berkaitan dengan permohonan pernyataan pailit. Pembatalan perbuatan hukum debitor yang telah dinyatakan pailit dengan pihak ketiga atau actio pauliana, seperti halnya dengan pembatalan perbuatan hukum lainnya, merupakan suatu sengketa yang penyelesaiannya harus dilakukan melalui suatu gugatan perdata di Pengadilan Negeri, sedangkan suatu permohonan tidak merupakan sengketa. Oleh karena itu permohonan pembatalan perbuatan hukum debitor yang telah dinyatakan pailit tidak dapat diajukan ke Pengadilan Niaga, melainkan ke Pengadilan Negeri menurut ketentuan hukum acara perdata yang berlaku bagi Pengadilan Negeri.

Permohonan actio pauliana kepada Pengadilan Niaga diajukan oleh kurator terhadap perbuatan hukum yang tidak diwajibkan berdasarkan Undang-Undang maupun perjanjian. Perbuatan hukum itu dilakukan oleh debitor dengan pihak ketiga. Akibat perbuatan hukum tersebut, pihak ketiga memperoleh kedudukan istimewa di antara para kreditor lain, 
tanpa adanya tambahan prestasi yang diterima oleh debitor. Dalil tersebut ada dalam R. Astuti Sitanggang, kurator Eddy Ondrawinata v. Soesanto Soetrisno. ${ }^{26}$

Permohonan ini berawal ketika Eddy Ondrawinata selaku debitor yang oleh Pengadilan Niaga telah dinyatakan pailit dalam putusan Pengadilan Niaga Nomor 27/Pailit/2002/PN.Niaga/Jkt.Pst. Akibat adanya pernyataan pailit tersebut, maka sejak 9 Oktober 2002 kurator berwenang untuk melaksanakan tugas pengurusan dan atau pemberesan atas harta debitor. Kurator dalam rangka melaksanakan tugas pengurusan dan pemberesan harta pailit melakukan pendataan kewajiban debitor dan juga harta pailit debitor yang ternyata hanya berupa sebidang tanah setempat yang dikenal dengan Taman Permata Buana, Jalan Pulo Bira Blok A8, Kelurahan Kembangan Utara, Kecamatan Kembangan, Jakarta Barat, seluas $250 \mathrm{~m}^{2}$ yang telah diserahkan kepada Susanto Soetrisno sebagai jaminan pembayaran yang jatuh temponya 9 Januari 2003. Debitor dengan Susanto Soetrisno memiliki hubungan pinjam meminjam uang dengan bunga 4,5\% per bulan dengan jumlah utang pokok dan bunga sebesar Rp 1.400.000.000,00. Sebagai jaminan atas pembayaran utang, debitor telah menyerahkan kepada Susanto Soetrisno tiga lembar bilyet giro Bank Central Asia dengan nominal Rp 500.000.000,00 yang jatuh temponya 9 Februari 2002, nominal Rp 735.000.000,00 yang jatuh temponya 9 Mei 2002, dan nominal Rp 50.000.000,00 yang jatuh temponya 9 Juni 2002. Perbuatan debitor menjaminkan sebidang tanah dengan memberi kuasa kepada Susanto Soetrisno adalah perbuatan yang tidak wajib, baik berdasarkan Undang-Undang maupun perjanjian antara debitor dan Susanto Soetrisno. Tindakan debitor menambah jaminan dan memberi kuasa kepada Susanto Soetrisno selain tidak diwajibkan juga telah menyebabkan Susanto Soetrisno memperoleh kedudukan istimewa di antara para kreditor lain, tanpa tambahan prestasi dari Susanto Soetrisno. Hal ini menjadikan para kreditor lain mengalami kerugian karena tanah yang menjadi jaminan merupakan satu-satunya harta pailit. Akibatnya, ketika debitor dinyatakan pailit ia tidak lagi memiliki harta pailit. Tindakan debitor yang menghapuskan utang Susanto Soetrisno dilakukan kurang lebih tiga bulan sebelum debitor dinyatakan pailit atau

\footnotetext{
${ }^{26}$ Putusan Pengadilan Niaga dalam R. Astuti Sitanggang, kurator Eddy Ondrawinatav. Soesanto Soetrisno, Nomor 02/Actio Pauliana/2003/PN.Niaga/Jkt.Pst., Putusan Mahkamah Agung pada tingkat kasasi Nomor 22 K/N/2003, dan Putusan Mahkamah Agung pada tingkat peninjauan kembali Nomor 13 PK/N/2003.
} 
pada saat debitor seharusnya dan sepatutnya telah mengetahui dan menyadari keadaan keuangannya, serta debitor sedang menghadapi tagihan atau tuntutan dari para kreditornya untuk pelunasan utangnya. Dengan demikian, sudah seharusnya dan sepatutnya debitor dan Susanto Soetrisno mengetahui dan menyadari tindakan debitor untuk menghapuskan piutang Susanto Soetrisno tersebut akan mengakibatkan kerugian bagi para kreditor lainnya. Terhadap permohonan actio pauliana oleh kurator, Pengadilan Niaga mengambil putusan pada 8 Juli 2003, yaitu menolak permohonan actio pauliana dari kurator. Terhadap putusan Pengadilan Niaga kurator mengajukan permohonan kasasi kepada Mahkamah Agung. Mahkamah Agung memberikan putusan mengabulkan permohonan kurator dengan pertimbangan judex factie telah salah menerapkan hukum, terutama ketentuan Pasal 41 Undang-Undang Nomor 4 Tahun 1998. Tindakan debitor pailit yang mengalihkan tanahnya seluas $250 \mathrm{~m}^{2}$ yang terletak di Taman Permata Buana, Kecamatan Kembangan guna pemenuhan utangnya kepada Susanto Soetrisno yang dilakukan dalam kurun waktu satu tahun sebelum pernyataan pailit, telah merugikan para kreditor dari debitor pailit. Selain itu debitor telah melakukan penjualan terhadap empat buah ekskavator dan telah menerima uang sejumlah Rp 1.500.000.000.000,00. Uang tersebut tidak semua dibayarkan kepada Susanto Soetrisno, namun dilakukan dengan menyerahkan bilyet giro yang ternyata tidak memiliki cukup dana meskipun sebenarnya debitor memiliki uang yang cukup dari hasil penjualan ekskavator. Dengan demikian debitor sengaja melakukan pembayaran, tidak dengan uang tunai tetapi dengan cara mengalihkan tanahnya. Terhadap putusan Mahkamah Agung pada tingkat kasasi itu, Susanto Soetrisno mengajukan permohonan peninjauan kembali kepada Mahkamah Agung. Permohonan tersebut ditolak dengan pertimbangan bahwa keberatan-keberatan yang diajukan tidak dapat dibenarkan, karena di dalam putusan kasasi yang dimohonkan peninjauan kembali tidak terdapat kesalahan berat dalam penerapan hukum.

Pendapat hakim Mahkamah Agung yang menolak permohonan actio pauliana diajukan ke Pengadilan Niaga akan menjadikan pemberesan harta pailit menjadi semakin lama. Putusan Mahkamah Agung yang menyatakan permohonan actio paulina merupakan kewenangan peradilan umum dapat menyebabkan proses pemberesan harta pailit terpisah-pisah, yang seharusnya dapat diselesaikan melalui suatu proses di Pengadilan Niaga. Pendapat Mahkamah Agung dalam Tuti Simorangkir kurator PT 
Fiskaragung Perkasa Tbk. v. PT Fiskaragung Perkasa Tbk. dkk., tidak diikuti oleh putusan Mahkamah Agung lainnya yang menerima dan memeriksa permohonan actio pauliana diperiksa dan diputuskan oleh Pengadilan Niaga, sebagaimana terlihat dalam R. Astuti Sitanggang, kurator Eddy Ondrawinata $v$. Soesanto Soetrisno yang telah diuraikan di atas.

Pendapat Mahkamah Agung dalam Tuti Simorangkir kurator PT Fiskaragung Perkasa Tbk. v. PT Fiskaragung Perkasa Tbk. dkk., menunjukkan Undang-Undang Kepailitan harus mempertegas pengaturan permohonan actio pauliana kepada Pengadilan Niaga, dan mengatur pula hukum acara pembuktian serta tenggang waktu penyelesaian yang cukup. Hal ini mengingat actio pauliana melibatkan kepentingan pihak ketiga yang harus diberikan kesempatan untuk membela kepentingannya dengan baik. ${ }^{27}$ Undang-Undang Nomor 37 Tahun 2004 belum secara tegas menentukan demikian. Undang-undang ini memang telah menetapkan actio pauliana diputuskan oleh Pengadilan Niaga yang daerah hukumnya meliputi daerah tempat kedudukan hukum debitor. ${ }^{28}$ Namun ketentuan penggunaan hukum acara yang sama termasuk pembatasan jangka waktu penyelesaiannya dengan hukum acara permohonan pernyataan pailit masih kurang memadai. Hal ini mengingat dalam ketentuan actio pauliana, debitor dan pihak dengan siapa perbuatan tersebut dilakukan seharusnya diberikan kesempatan untuk melakukan pembuktian sebaliknya terhadap permohonan actio pauliana terhadap mereka. ${ }^{29}$ Untuk melakukan pembuktian sebagaimana dimaksud dalam Undang-Undang Kepailitan tentunya memerlukan waktu yang lebih panjang dibandingkan dengan permohonan pernyataan pailit.

\section{Beberapa Kendala Penerapan Actio Pauliana}

Dalam praktik penegakan Undang-Undang Kepailitan, ternyata ketentuan actio pauliana belum sepenuhnya dapat melindungi kepentingan kreditor dengan beberapa alasan. Pembuktian dalam actio pauliana tidak dapat dilakukan secara sederhana. Pembuktian actio pauliana berbeda dengan pembuktian sederhana dalam kepailitan. Apabila hal ini diperiksa di Pengadilan Negeri, dapat saja penyelesaian kepailitan menjadi berlarut-

\footnotetext{
${ }^{27}$ Bandingkan dengan Elijana et. al., op. cit., hal. 19. Lihat pula penjelasan Pasal 3 ayat (1) Undang-Undang Nomor 37 Tahun 2004.

${ }^{28}$ Penjelasan Pasal 3 ayat (1) Undang-Undang Nomor 37 Tahun 2004.

${ }^{29}$ Pasal 42 Undang-Undang Nomor 37 Tahun 2004.
} 
larut. ${ }^{30}$ Padahal, umumnya debitor langsung memindahkan harta-harta bergerak termasuk rekening-rekeningnya yang ada di bank setelah adanya pernyataan pailit, dengan tujuan untuk menghindari pemberesan harta oleh kurator. ${ }^{31}$ Khusus untuk harta debitor yang berbentuk badan hukum yang pemilikannya atas nama pribadi tetap dipertahankan atas nama pemegang saham, dan dilakukan perikatan-perikatan tertentu dengan pihak lain secara back date. Transaksi semacam ini mudah terjadi karena lemahnya penegakan hukum dalam bidang yang berkaitan dengan ketentuan Undang-Undang Nomor 3 Tahun 1982 tentang Wajib Daftar Perusahaan, khususnya kewajiban penyampaian laporan keuangan audit tahunan. ${ }^{32}$

Kurator mengalami kesulitan untuk dapat mengakses dokumen yang dimiliki oleh debitor. Dalam perkara Ibist, dokumen-dokumen dibawa pergi oleh Wandi Sofian, sehingga kurator sama sekali tidak mengetahui besarnya harta kekayaan Ibist. ${ }^{33}$ Sementara itu sejumlah harta kekayaan Ibist telah disita oleh Pengadilan Negeri Bandung dengan Penetapan Nomor 36/Pen.Pid/2007/PN.Bdg pada 5 Januari 2007 untuk keperluan pembuktian dalam perkara pidana. ${ }^{34}$ Masih dalam perkara Ibist, taksiran terhadap nilai harta pailit terlalu kecil, dan adanya upaya debitor untuk menghindari kewajibannya. ${ }^{35}$

Tindakan yang dilakukan oleh debitor dengan maksud untuk merugikan kepentingan kreditor sebelum putusan pernyataan pailit biasanya dilakukan dengan cara memecah tagihan 'inter company loan' dengan menggunakan ketentuan cessie dalam Pasal 613 Burgerlijk Wetboek. Jika itu sudah dilaksanakan, pihak advokat debitor akan bersikap melindungi debitor dan harta debitor secara berlebih-lebihan (over protected). Cara lain yang biasa dilakukan adalah debitor melakukan pendekatan kepada kreditor-kreditor tertentu dengan kompensasi tertentu. Misalnya, pembayaran sebagian utang atau tagihannya akan diambil alih oleh

\footnotetext{
${ }^{30}$ http:/ / www.hukumonline.com/ detail.asp?id=1639\&cl=Berita, "Pengadilan Niaga Wadah Ketidakpastian Baru," 15 Januari 2001.

${ }^{31} \mathrm{http}: / /$ www.hukumonline.com/detail.asp?id=16408\&cl=Fokus, "Rendah, Pemulihan Aset dalam Kepailitan," 27 Maret 2007.

${ }^{32}$ Ibid.

${ }^{33}$ http:/ / www.hukumonline.com/detail.asp?id=16321\&cl=Berita, "Kurator Ibist Rencanakan Actio Pauliana Secepatnya," 8 Maret 2007.

${ }^{34} \mathrm{http}$ // / www.hukumonline.com/detail.asp?id=16190\&cl=Berita, "Kepailitan Ibist Consult, Kurator Sudah Berkoordinasi dengan Polisi," 12 Februari 2007.

${ }^{35}$ http:/ / www.hukumonline.com/detail.asp?id=16321\&cl=Berita, loc. cit.
} 
perusahaan terafiliasi. Tujuannya agar memberikan dukungan dalam rapat-rapat kreditor maupun voting rapat kreditor. Selain itu, debitor juga tidak jarang meminta kreditor atau pemegang saham atau afiliasinya agar membeli tagihan-tagihan kreditor melalui Special Purpose Vehicle dengan harga tertentu. Selanjutnya Special Purpose Vehicle itu akan menjadi kreditor 'baru' yang akan hadir dalam rapat-rapat kreditor. Cara-cara seperti ini terjadi atas tagihan-tagihan yang timbul dari surat berharga atas tunjuk yang tidak akan tercatat dalam pembukuan debitor. Caracara di atas akan menyulitkan pembentukan panitia kreditor. Kalau pun terbentuk, maka tidak akan efektif mengingat panitia kreditor diisi oleh 'para kreditor' yang merupakan teman debitor. Cara ini juga sulit dideteksi oleh pihak kurator. Kalau pun kurator mengetahuinya, kurator enggan untuk melakukan actio pauliana. Padahal, Undang-Undang Kepailitan memberikan sarana bagi kurator untuk mencegah atau pun membatalkan tindakan-tindakan sebagaimana dipaparkan di atas. ${ }^{36}$

Kesulitan yang ditemukan untuk mendeteksi keberadaan harta debitor pailit antara lain minimalnya tingkat partisipasi nasabah, polisi, kejaksaan maupun perbankan, karena mereka tidak paham Undang-Undang Kepailitan. Misalnya, tidak ada pandangan yang sama dalam hal hubungan tugas dengan hakim Pengadilan Niaga dan hakim pengawas maupun pihak eksternal terkait seperti perbankan, Direktorat Jenderal Pajak, dan Direktorat Jenderal Piutang dan Lelang Negara. Contohnya kurator mengalami hambatan dalam mengakses rekening debitor pailit di bank, dengan alasanya adanya ketentuan rahasia bank. Hal ini menyebabkan kerja sama dengan pihak perbankan berkaitan dengan pemblokiran rekening milik debitor pailit tidak berjalan dengan baik. Para kurator mengalami dilema. Jika kurator tidak mengajukan pemblokiran, pasti akan ditegur oleh Bank Indonesia dan terancam sanksi pidana, namun ketika mengajukan pemblokiran, pihak bank tidak mengindahkan permohonan kurator. ${ }^{37}$ Demikian juga dengan adanya ketentuan tentang masa kadaluarsa hak tagih pajak selama sepuluh tahun yang akan menyulitkan kurator karena harus menunggu sampai masa kedaluwarsa itu sebelum dapat membagikan hasil pemberesan kepada kreditor konkuren. ${ }^{38}$

\footnotetext{
${ }^{36}$ http:/ / www.hukumonline.com/detail.asp?id=16408\&cl=Fokus, loc. cit.

${ }^{37}$ Ibid.

${ }^{38}$ http://www.pikiran-rakyat.com/cetak/1003/30/06x2.htm, "Kasus
} Kepailitan 2003 Turun." 30 Oktober 2003. 


\section{Simpulan}

Pembuktian terhadap permohonan actio pauliana pada umumnya adalah tidak sederhana, sehingga pembuktian sederhana dalam UndangUndang Kepailitan tidak mudah diterapkan. Namun, pendapat Mahkamah Agung yang menyatakan bahwa actio pauliana bukan kewenangan Pengadilan Niaga tidak lah tepat, karena akan memperlama proses pemberesan harta pailit. Di samping pembuktiannya yang tidak sederhana, kendala lain dalam penyelesaian permohonan actio pauliana antara lain perbuatan hukum yang dilakukan oleh debitor yang merugikan para kreditor sulit dideteksi, terbatasnya kewenangan kurator untuk mengungkapkan hal tersebut, dan kurangnya kerjasama teknis dengan instansi penegak hukum lain dalam mengungkapkan actio pauliana. Agar perlindungan terhadap kepentingan kreditor melalui actio pauliana dapat dilakukan, maka diperlukan peraturan pelaksana tentang hukum acara pembuktian actio pauliana yang implementatif.

\section{Daftar Pustaka}

Acles \& Dorr, "A Critical Analysis of the New Uniform Fraudulent Transfer Act," 1985 Univercity of Illinois Law Review 527, 1985.

Cook \& Mendales, "Uniform Fraudulent Transfer Act: An Introductory Critique," 62 American Bankruptcy Law Journal 87, 1988.

Daniel V. Davidson, et. al., Comprehensive Business Law Prinsiples and Cases, Boston: Kent Publishing Company, 1987.

Dawson v. Myers, 622 F 2d. 1304, 9th Cir., 1980.

Douglas G. Baird \& Thomas H. Jackson, “Fraudulent Conveyance Law and its Proper Domain," 38 Vanderbilt Law Review 829, 1985.

Elijana, et. al., Penelitian Hukum tentang Penyelesaian Sengketa melalui Peradilan Niaga, Jakarta: BPHN dan Depkeh dan HAM, 2000.

Frank R. Kennedy “Involuntary Fraudulent Transfers” 9 Cardozo Law Review 531, Desember 1987.

Fred B.G. Tumbuan, “Mencermati Pokok-pokok Undang-Undang Kepailitan yang Diubah Perpu No. 1/1998," Newsletter No. 33/IX/Juni/1998

http:/ / www.hukumonline.com/detail.asp?id=16190\&cl=Berita, "Kepailitan Ibist Consult, Kurator Sudah Berkoordinasi dengan Polisi," 12 Februari 2007.

http:/ / www.hukumonline.com/detail.asp?id=16321\&cl=Berita, “Kurator Ibist Rencanakan Actio Pauliana Secepatnya," 8 Maret 2007. 
http: / / www.hukumonline.com/ detail.asp?id=1639\&cl=Berita,

“Pengadilan Niaga Wadah Ketidakpastian Baru," 15 Januari 2001.

http: / / www.hukumonline.com/detail.asp?id=16408\&cl=Fokus,

"Rendah, Pemulihan Aset dalam Kepailitan," 27 Maret 2007.

http:/ / www.pikiran-rakyat.com/cetak/1003/30/06x2.htm, "Kasus

Kepailitan 2003 Turun." 30 Oktober 2003.

John D. Donell, et. al., Law for Business, Illionis: Richard D. Irwin, Inc., 1983.

Marco Lantelme, "Italy: Insolvency - Claw Back," Journal of International Banking Law and Regulation 20 (10), 2005.

McCoid, "Constructively Fraudulent Conveyances: Transfers for Inadequate Consideration," 62 Texax Law Review 639, 1983.

Michael Bagge, "Planned Poverty's Pitfalls And Pratfalls - Ain't We Got Fun?" 69-Aug New York State Bankruptcy Journal 26, Juli/Agustus, 1997.

Oksana Lashko, “Enhancing Creditor Recovery, Should Services Be Deemed "Property" for the Putpose of Fraudulent Transfer Law?" 72 Brooklyn Law Review 317, 2006.

Putusan Pengadilan Niaga dalam William E. Daniel kurator PT Ometraco Multi Arta v. PT Ometraco Multi Arta, dkk., Nomor 01/Actio Pauliana/ 2000/PN.Niaga/Jkt.Pst., dan Putusan Mahkamah Agung pada tingkat kasasi Nomor 15 K/N/2000.

Putusan Pengadilan Niaga dalam Tuti Simorangkir, Kurator PT Fiskaragung Perkasa Tbk. v. PT Fiskaragung Perkasa Tbk. dkk., Nomor 03/Actio Pauliana/2000/PN.Niaga/Jkt.Pst., Putusan Mahkamah Agung pada tingkat kasasi Nomor 16 K/N/2000, dan Putusan Mahkamah Agung pada tingkat peninjauan kembali Nomor 12 PK/N/2000.

Putusan Pengadilan Niaga dalam R. Astuti Sitanggang, kurator Eddy Ondrawinata v. Soesanto Soetrisno, Nomor 02/Actio Pauliana/2003/ PN.Niaga/Jkt.Pst., Putusan Mahkamah Agung pada tingkat kasasi Nomor 22 K/N/2003, dan Putusan Mahkamah Agung pada tingkat peninjauan kembali Nomor 13 PK/N/2003.

Rosenberg, "Intercorporate Guaranties and the Law of Fraudulent Conveyances: Lender Beware," 125 University of Pennsylvania Law Review 235, 976.

Sandy Shandro, "Italian Law Reform," 24 American Bankruptcy Institute Journal 18, Oktober, 2005.

Undang-Undang Nomor 37 Tahun 2007 tentang Kepailitan dan Penundaan Kewajiban Pembayaran Utang.

Undang-Undang Nomor 4 Tahun 1998 tentang Kepailitan. 
Victor Situmorang \& Hendri Soekarso, Pengantar Hukum Kepailitan di Indonesia, Jakarta: Rineka Cipta, 1994. 